\title{
Preserved Incretin Activity of Glucagon-like Peptide 1 [7-36 Amide] but Not of Synthetic Human Gastric Inhibitory Polypeptide in Patients with Type-2 Diabetes Mellitus
}

\author{
Michael A. Nauck, Markus M. Heimesaat, Cathrine Ørskov, ${ }^{\star}$ Jens J. Holst, ${ }^{\star}$ Reinhold Ebert, and Werner Creutzfeldt \\ Division of Gastroenterology and Endocrinology, Department of Medicine, Georg-August-Universität, Göttingen, \\ D-3400 Federal Republic of Germany; and *Department of Clinical Chemistry, Rigshospitalet, and \\ ${ }^{\ddagger}$ Department of Medical Physiology C, Panum Institute, Copenhagen, Denmark
}

\begin{abstract}
In type- 2 diabetes, the overall incretin effect is reduced. The present investigation was designed to compare insulinotropic actions of exogenous incretin hormones (gastric inhibitory peptide [GIP] and glucagon-like peptide 1 [GLP-1] [7-36 amide]) in nine type-2 diabetic patients (fasting plasma glucose 7.8 mmol/liter; hemoglobin $\left.A_{1 c} 6.3 \pm 0.6 \%\right)$ and in nine age- and weight-matched normal subjects. Synthetic human GIP (0.8 and $2.4 \mathrm{pmol} / \mathrm{kg} \cdot \mathrm{min}$ over $1 \mathrm{~h}$ each $),$ GLP-1 [ 7-36 amide] (0.4 and $1.2 \mathrm{pmol} / \mathrm{kg} \cdot \mathrm{min}$ over $1 \mathrm{~h}$ each ), and placebo were administered under hyperglycemic clamp conditions $(8.75 \mathrm{mmol} /$ liter) in separate experiments. Plasma GIP and GLP-1 [7-36 amide] concentrations (radioimmunoassay) were comparable to those after oral glucose with the low, and clearly supraphysiological with the high infusion rates. Both GIP and GLP-1 [7-36 amide] dose-dependently augmented insulin secretion (insulin, $C$-peptide) in both groups $(P<0.05)$. With GIP, the maximum effect in type-2 diabetic patients was significantly lower (by 54\%; $P<0.05$ ) than in normal subjects. With GLP-1 [7-36 amide] type- 2 diabetic patients reached $71 \%$ of the increments in C-peptide of normal subjects (difference not significant ). Glucagon was lowered during hyperglycemic clamps in normal subjects, but not in type-2 diabetic patients, and further by GLP-1 [ 7-36 amide] in both groups $(P<0.05)$, but not by GIP. In conclusion, in mild type-2 diabetes, GLP-1 [7-36 amide], in contrast to GIP, retains much of its insulinotropic activity. It also lowers glucagon concentrations. (J. Clin. Invest. 1993.91:301-307.) Key words: enteroinsular axis • gastric inhibitory peptide $\cdot$ glucagon-like peptide 1 [7-36 amide] $\cdot$ hyperglycemic clamp • incretin hormones • pancreatic glucagon
\end{abstract}

\section{Introduction}

In normal subjects, oral glucose enhances insulin secretion more than does intravenous glucose infusion (incretin effect; 1-4). This augmentation of insulin secretion is due to the secretion and action of gut hormones with insulinotropic activity, namely gastric inhibitory polypeptide (GIP, ${ }^{1}$ also called

Address reprint requests to Dr. Nauck, Division of Gastroenterology and Endocrinology, Department of Internal Medicine, Georg-AugustUniversität, Robert-Koch-Strasse 40, D-3400 Göttingen, FRG.

Received for publication 12 May 1992 and in revised form $17 \mathrm{Au}$ gust 1992.

J. Clin. Invest.

(C) The American Society for Clinical Investigation, Inc. $0021-9738 / 93 / 01 / 0301 / 07 \$ 2.00$

Volume 91, January 1993, 301-307 glucose-dependent insulinotropic hormone; 5, 6) from the upper gut ( 7 ) and glucagon-like peptide 1 [ 7-36 amide] (GLP-1 [7-36 amide]; proglucagon 78-107 amide; 8-11) from the lower gut $(12,13)$. In type- 2 diabetic patients, the incretin effect is reduced or lost $(4,14)$. This does not seem to be a consequence of deficient release of GIP, in that most studies found a normal or even enhanced secretion of this incretin hormone in type- 2 diabetic patients (for review, see references 15 and 16). According to a recent study, basal plasma concentrations of immunoreactive GLP-1 are higher and responses to oral glucose are greater in type-2 diabetic patients (17).

By using GIP of the porcine amino acid sequence, several studies have uniformly described a reduced insulinotropic effectiveness in type-2 diabetic patients as compared to normal subjects $(18,19)$. Human GIP differs by two amino acids (in positions 18 and 34, respectively) from porcine $\operatorname{GIP}(20,21)$. Insulinotropic effects of human GIP in type- 2 diabetic patients have not yet been studied. Similarly, no detailed studies comparing insulinotropic actions of GLP-1 [ 7-36 amide] in type-2 diabetic patients and normal subjects are available. Preliminary results suggest that GLP-1 [7-36] in pharmacological doses can stimulate insulin secretion in type- 2 diabetic patients (22). In streptozotocin-diabetic rats, on the other hand, the insulinotropic effectiveness of both GIP and GLP-1 [7-36 amide] was reduced (23).

In the isolated perfused pancreas of the rat, pig, or dog, GLP-1 [7-36 amide] or [7-37] suppressed pancreatic glucagon concentrations (23-26). Except for preliminary data $(10,27)$, the conditions under which glucagon secretion is regulated by GLP-1 [7-36 amide] in normal humans and type-2 diabetic patients have not been defined.

The present study was designed to compare, at identical plasma glucose concentrations (hyperglycemic clamp experiments), the insulinotropic and glucagon-lowering actions of both synthetic human GIP and GLP-1 [ 7-36 amide], infused at both approximately physiological and pharmacological concentrations, in matched groups of type- 2 diabetic patients and normal subjects.

\section{Methods}

Study protocol. The study protocols were approved by the ethics committee of the medical faculty of the Georg-August-Universität, Göttingen, on 21 April, 1988. Written informed consent was obtained from all participants.

Subjects. Nine type-2 diabetic patients and nine subjects with normal glucose tolerance (normal kidney function and liver enzymes; for

1. Abbreviations used in this paper: GIP, gastric inhibitory peptide; GLP-1, glucagon-like peptide 1 . 
Table I. Patient/Subject Characteristics

\begin{tabular}{|c|c|c|c|}
\hline $\begin{array}{l}\text { Parameter } \\
\text { (unit) }\end{array}$ & $\begin{array}{l}\text { Type-2 } \\
\text { diabetic } \\
\text { patients }\end{array}$ & $\begin{array}{l}\text { Normal } \\
\text { subjects }\end{array}$ & $\begin{array}{l}\text { Significance } \\
\text { of the } \\
\text { difference } \\
(P \text { value })\end{array}$ \\
\hline Sex (male/female) & $4 / 5$ & $5 / 4$ & 1.00 \\
\hline Age $(y r)$ & $59 \pm 10$ & $59 \pm 11$ & 0.96 \\
\hline $\begin{array}{l}\text { Body mass index } \\
\left(\mathrm{kg} / \mathrm{m}^{2}\right)\end{array}$ & $28.6 \pm 3.1$ & $26.8 \pm 4.1$ & 0.27 \\
\hline $\begin{array}{l}\text { Duration of diabetes } \\
(y r)\end{array}$ & $\begin{array}{c}8 \pm 9 \\
(0-20)\end{array}$ & - & - \\
\hline $\begin{array}{l}\text { Fasting plasma glucose } \\
(\mathrm{mmol} / \text { liter })\end{array}$ & $7.8 \pm 0.4$ & $5.5 \pm 0.2$ & 0.0007 \\
\hline $\begin{array}{l}\text { 120-min plasma glucose* } \\
\text { (mmol/liter) } \\
\text { Hemoglobin } \mathrm{A}_{1}(\%)\end{array}$ & $\begin{array}{r}15.7 \pm 0.7 \\
6.3 \pm 0.6\end{array}$ & $\begin{array}{l}6.4 \pm 0.3 \\
5.3 \pm 0.3\end{array}$ & $\begin{array}{l}0.0003 \\
0.0015\end{array}$ \\
\hline
\end{tabular}

Mean \pm SD. ${ }^{*}$ After $75 \mathrm{~g}$ of oral glucose.

characteristics see Table I) participated in the study. In two type-2 diabetic patients, sulfonylurea treatment was discontinued at least $3 \mathrm{wk}$ before performing the study. In none of the type- 2 diabetic patients retinopathy, nephropathy, or neuropathy were present. Two type-2 diabetic patients and one normal subject had hypertension treated by diuretics and / or calcium channel blockers. On the study days, all medication was withheld until the end of the experiments.

Peptides. Synthetic human GIP and GLP-1 [ 7-36 amide] were purchased from Bissendorf Biochemicals GmbH, Hannover, FRG. The same lot numbers were used as in a previous study (GIP: PGAS 125, Lot WF 100, net peptide content 79.4\%; GLP-1 [7-36 amide]: PGAS 242 , Lot ZE 865 , net peptide content $79.3 \%$; 11 ). The peptides were dissolved in $0.9 \% \mathrm{NaCl}$ containing $1 \%$ human serum albumin. After filtration through $0.2-\mu \mathrm{m}$ nitrocellulose filters (Millipore Corp., Bedford, MA), they were checked for sterility by means of standard bacterial culture methods, and for pyrogens using a Limulus assay (Pyroquant 50, Walldorf, FRG). No contaminants were detected. Net peptide content rather than gross weight was used for dose calculations.

Experimental procedures. Each participant took part in four examinations: $(a)$ an oral glucose challenge $(75 \mathrm{~g} / 300 \mathrm{ml}) ;(b)$ a hyperglycemic "clamp" experiment aiming at a capillary plasma glucose concentration of $8.75 \mathrm{mmol} /$ liter, maintained over $210 \mathrm{~min}$, with the subsequent intravenous bolus injection of glucagon $(1 \mathrm{mg}) ;(c)$ a hyperglycemic "clamp" experiment with exogenous synthetic human GIP at an infusion rate resulting, according to prior experience $(6,10$, 11 ), in an approximately physiological increment in GIP plasma concentrations ( $0.8 \mathrm{pmol} \mathrm{kg}^{-1} \mathrm{~min}^{-1}$ between 30 and $90 \mathrm{~min}$ ) and, subsequently, a three times higher infusion rate, in order to increase plasma concentrations to a supraphysiological range $\left(2.4 \mathrm{pmol} \mathrm{kg}^{-1} \mathrm{~min}^{-1}\right.$ between 90 and $150 \mathrm{~min}$ ); and $(d)$ a hyperglycemic "clamp" experiment with exogenous synthetic GLP-1 [ 7-36 amide] at an infusion rate meant to result in an approximately physiological increment in GLP-1 [7-36 amide] plasma concentrations $\left(10,11 ; 0.4 \mathrm{pmol} \mathrm{kg}^{-1} \mathrm{~min}^{-1}\right.$ between 30 and $90 \mathrm{~min}$ ) and, subsequently, a three times higher infusion rate in order to increase plasma concentrations to a supraphysiological range ( $1.2 \mathrm{pmol} \mathrm{kg}^{-1} \mathrm{~min}^{-1}$ between 90 and $150 \mathrm{~min}$ ).

At least $1 \mathrm{wk}$ was allowed to pass between experiments. Experiments $b-d$ were performed in randomized order.

The tests were performed in the morning after an overnight fast. A distal forearm vein was punctured with a teflon cannula and kept patent using physiological saline for blood sampling. For hormone injection or infusion and for intravenous glucose infusions, a second cannula was placed into a large vein on the contralateral arm.

After drawing basal blood specimens, at $0 \mathrm{~min}$, either oral glucose was administered $(75 \mathrm{~g} / 300 \mathrm{ml} \mathrm{O}$. G. T., Boehringer Mannheim $\mathrm{GmbH}$, Mannheim, FRG), or an intravenous glucose injection aiming at an elevation in plasma glucose to $\sim 8.75 \mathrm{mmol} /$ liter, followed by a hyperglycemic glucose clamp (28), was started. For this purpose, capillary plasma glucose was immediately determined in samples obtained every $5 \mathrm{~min}$. The infusion rate was adjusted in response to deviations from the predetermined hyperglycemic glucose concentration that was to be maintained. $8.75 \mathrm{mmol} /$ liter was chosen because of the known glucose-dependence of insulinotropic GIP and GLP-1 [7-36 amide] actions $(5,6,10,11)$.

At the end $(210 \mathrm{~min})$ of protocol $b(0.9 \% \mathrm{NaCl}$ containing $1 \%$ human serum albumin had been infused as placebo), $1 \mathrm{mg}$ glucagon (Novo Nordisk, Bagsvaerd, DK) was injected intravenously as a bolus. Glucose infusion was continued at the same rate that was needed to maintain a steady state immediately before glucagon injection.

Blood specimens. Blood was drawn, at the times shown in the figures, into heparinized tubes (immunoreactive [IR] insulin and C-peptide measurements). For glucagon and GLP-1 [7-36 amide] measurements tubes containing EDTA and aprotinin (Trasylol; $20000 \mathrm{KIU} /$ $\mathrm{ml}, 200 \mu \mathrm{l} / 10 \mathrm{ml}$ blood; Bayer AG, Leverkusen, FRG) were used. A sample was stored in NaF (Microvette CB 300, Sarstedt, Nümbrecht, FRG) for the subsequent measurement of glucose. 3, 6, and $10 \mathrm{~min}$ after the glucagon bolus (protocol $b$ ) blood was drawn to estimate the acute $B$ cell response. After centrifugation, plasma for hormone analyses was kept frozen at $-30^{\circ} \mathrm{C}$.

Laboratory determinations. Glucose was measured using a glucose analyzer 2 (Beckman Instruments, Inc., Munich, FRG; glucose oxidase method). Plasma IR-insulin and C-peptide were determined using commercial radioimmunoassay kits (Insulin RIA 100, Pharmacia, Freiburg, FRG; RIA-mat C-peptide II, Byk-Sangtec Diagnostika, Dietzenbach, FRG), with human insulin and C-peptide as standard.

IR-GIP was assayed according to Kuzio et al. (29), using antiserum Gö 77/5, and human GIP (Bissendorf Biochemicals) for tracer preparation and as standard. Intra- and interassay coefficients of variation were $15 \%$ and $18 \%$, respectively.

IR-GLP-1 was measured in ethanol-extracted plasma as described by Ørskov and Holst (30), using antiserum 2135 (final dilution 1:150,000) and synthetic GLP-1 [7-36 amide] (Peninsula Laboratories, St. Helens, UK) for tracer preparation and as standard. This antiserum cross-reacts with equal strength with all peptides containing the proglucagon 78-107 amide sequence, regardless of amino- or carboxylterminal extensions. Intra- and interassay coefficients of variation were $<9 \%$ and $<14 \%$, respectively.

Pancreatic glucagon was assayed in ethanol-extracted plasma using antibody 4305 (31).

Calculations and statistical analysis. Person characteristics are shown as mean $\pm \mathrm{SD}$, and experimental results are reported as mean \pm SEM.

Integration was carried out according to the trapezoidal rule. Glycemic excursions and secretory responses were analyzed as integrated incremental values over or as reactive excursions below baseline values (glucose, glucagon).

Significances of differences were tested using nonparametric tests (Mann-Whitney's U-test for group comparisons and the Wilcoxon signed rank test for paired comparisons). A $P$ value $<0.05$ was taken to indicate significant differences.

\section{Results}

In type- 2 diabetic patients, an oral glucose challenge elicited the typical slow increment in insulin and C-peptide concentrations, whereas the overall integrated incremental responses were not different from those in normal subjects (Fig. 1, B and $C$ ).

GIP responses after oral glucose tended to be lower in the type- 2 diabetic patients (by $31 \%, P=0.10$; difference not signif- 

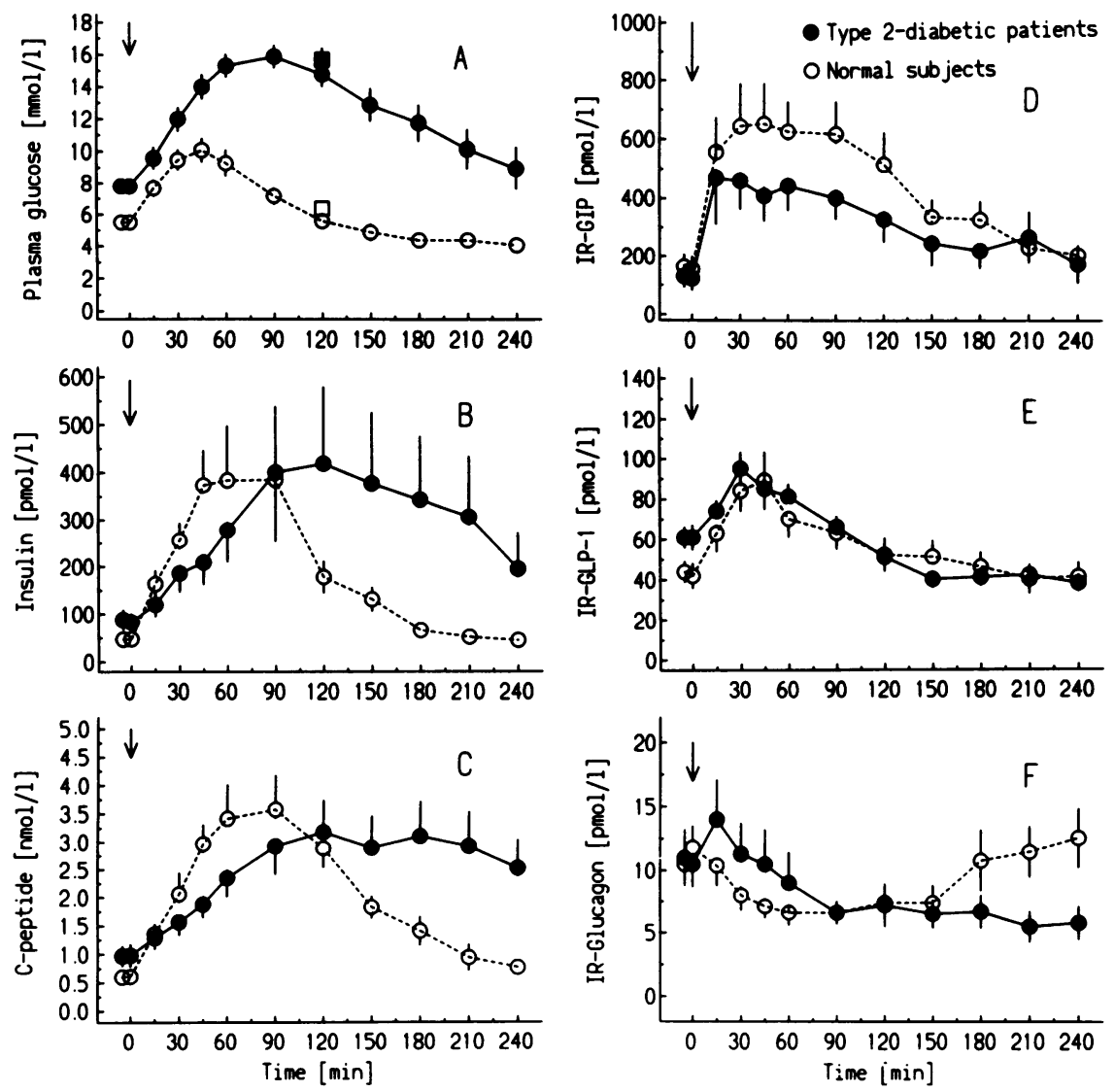

Figure 1. Responses of plasma glucose $(A)$, insulin $(B)$, C-peptide $(C)$, immunoreactive GIP $(D)$, immunoreactive GLP-1 (antiserum 2135; $E$ ) and pancreatic glucagon (antiserum $4305 ; F$ ) to oral glucose ingestion (arrows) in type- 2 diabetic patients (filled symbols) and normal subjects (open symbols). Mean \pm SEM. Capillary glucose values $120 \mathrm{~min}$ after oral glucose are shown as squares. For statistical analysis, see text. icant) (Fig. 1 D). Basal concentrations of immunoreactive GLP-1 were higher in type- 2 diabetic patients ( $61 \pm 5$ vs. $43 \pm 5$ pmol/liter, $P=0.034$ ), whereas GLP-1 [7-36 amide] integrated incremental responses after oral glucose were lower than in normal subjects (Fig. $1 E ; P=0.047$ ). The peak concentrations reached, however, where similar in type- 2 diabetic patients and normal subjects.

Pancreatic glucagon, in the basal state, was similar in both groups. Glucagon concentrations were suppressed by oral glucose in both type- 2 diabetic patients and normal subjects, although plasma glucose increments were clearly higher in type-2 diabetic patients (Fig. 1, $A$ and $F$ ).

Hyperglycemic clamp conditions led to comparable capillary glucose concentrations $(\sim 8.75 \mathrm{mmol} /$ liter, coefficient of variation between $2.8 \pm 0.3 \%$ and $4.8 \pm 0.4 \%$ ) for type- 2 diabetic patients and normal subjects throughout the experiments with and without administration of insulinotropic peptide hormones (not shown).

During intravenous infusions of GIP at the lower rate $(0.8$ pmol kg ${ }^{-1} \mathrm{~min}^{-1}$; Fig. 2, $A$ and $C$ ), plasma concentrations were comparable to peak responses after the glucose challenge (Fig. $1 D)$, while with the higher infusion rate $\left(2.4 \mathrm{pmol} \mathrm{kg}^{-1}\right.$ min $\left.^{-1}\right)$, clearly supraphysiological concentrations were reached (Fig. 2, $A$ and $C$ ).

With GLP-1 [7-36 amide] infusions at the lower rate (0.4 pmol kg ${ }^{-1} \mathrm{~min}^{-1}$; Fig. 2, $B$ and $D$ ), similar plasma concentrations were measured as after endogenous stimulation with oral glucose (Fig. $1 E$ ). The higher rate $\left(1.2 \mathrm{pmol} \mathrm{kg}^{-1} \mathrm{~min}^{-1}\right)$ led to supraphysiological concentrations. The plasma levels reached during intravenous infusions of GIP and GLP-1 [ 7-36 amide] did not differ at any dose between type-2 diabetic patients and normal subjects.

Both GIP and GLP-1 [ 7-36 amide] dose-dependently stimulated insulin secretion (insulin and C-peptide) in type- 2 diabetic patients and normal subjects (Fig. 3; Table II). GIP, at the low infusion rate, significantly stimulated insulin secretion, but to a lesser extent (lower C-peptide concentrations) than did oral glucose (Figs. 1 and 3). The difference between responses in type-2 diabetic patients and normal subjects was not significant (Table II). With the high rate of GIP infusion, a greater insulin secretory response was elicited in normal subjects, but in type-2 diabetic patients even the pharmacological concentrations of GIP reached ( $1,053 \pm 108$ pmol/liter ) only marginally stimulated insulin secretion. Whereas in normal subjects the glucose infusion had to be increased owing to GIP-stimulated insulin release, the glucose infusion rate hardly had to be increased in type- 2 diabetic patients (Table II). On the other hand, exogenous GLP-1 [7-36 amide] led to significantly higher increments in insulin and C-peptide than GIP at both infusion rates and in both type- 2 diabetic patients and normal subjects (Fig. 3; Table II). At the low and the high dose, the increment in C-peptide concentrations in type-2 diabetic patients was approximately two thirds of the responses in normal subjects ( Table II). The difference between type- 2 diabetic patients and normal subjects was not significant. Glucose infusion had to be increased in normal subjects, and, to a lesser extent also in type- 2 diabetic patients, in order to maintain a constant glucose concentration during the hyperglycemic clamp experiments (Table II). At the high infusion rates for GIP and GLP-1 [ 7-36 amide ], respectively, integrated C-pep- 

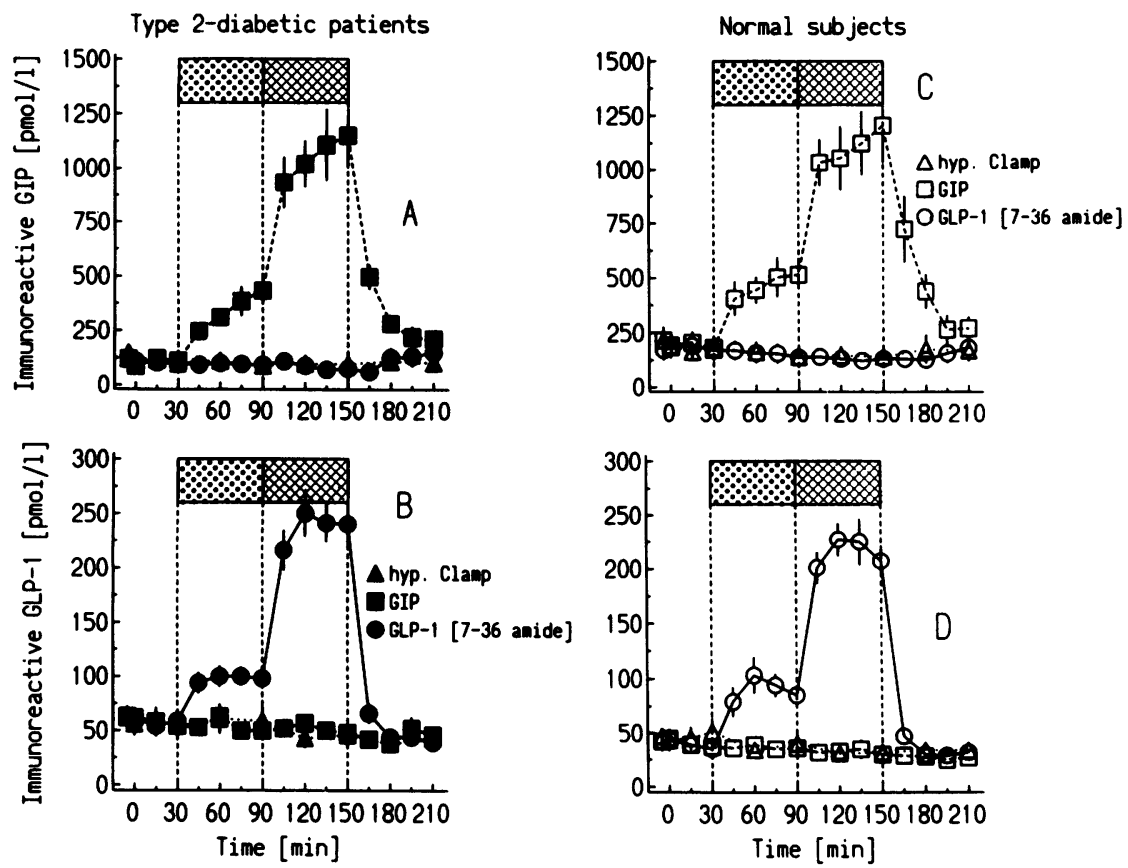

Figure 2. Immunoreactive GIP ( upper panels) and GLP-1 (antibody 2135; lower panels) during hyperglycemic clamp experiments with and without the infusion of synthetic human GIP or GLP-1 [7-36 amide] in type-2 diabetic patients (left panels) and normal subjects (right panels). Mean \pm SEM. The dotted lines separate periods of

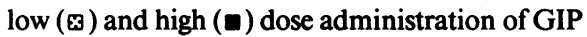
or GLP-1 [ 7-36 amide].

tide incremental responses in type- 2 diabetic patients were $46 \pm 9 \%$ and $71 \pm 17 \%$ of the mean responses in normal subjects ( $p=0.028$ for the comparison of GIP and GLP-1 [7-36 amide ] effects).

In type-2 diabetic patients, the insulin secretory response (C-peptide) to GLP-1 [7-36 amide] correlated closely to the one after intravenous glucagon injection $(r=0.958 ; P$ $<0.001$ ). This was not the case in normal subjects.

Pancreatic glucagon concentrations, which were not differ- ent between type-2 diabetic patients and normal subjects in the basal state, were suppressed during the hyperglycemic clamp in normal subjects (by $65 \%, P=0.012$ ), but not in type-2 diabetic patients $(P=0.28$; Fig. 4$)$. Exogenous GIP was without a major effect on pancreatic glucagon concentrations in normal subjects, whereas GLP-1 [7-36 amide] slightly, but significantly lowered pancreatic glucagon in normal subjects $(P$ $=0.018$ and 0.012 for the low and high dose, respectively). This effect was much more prominent in type-2 diabetic pa-
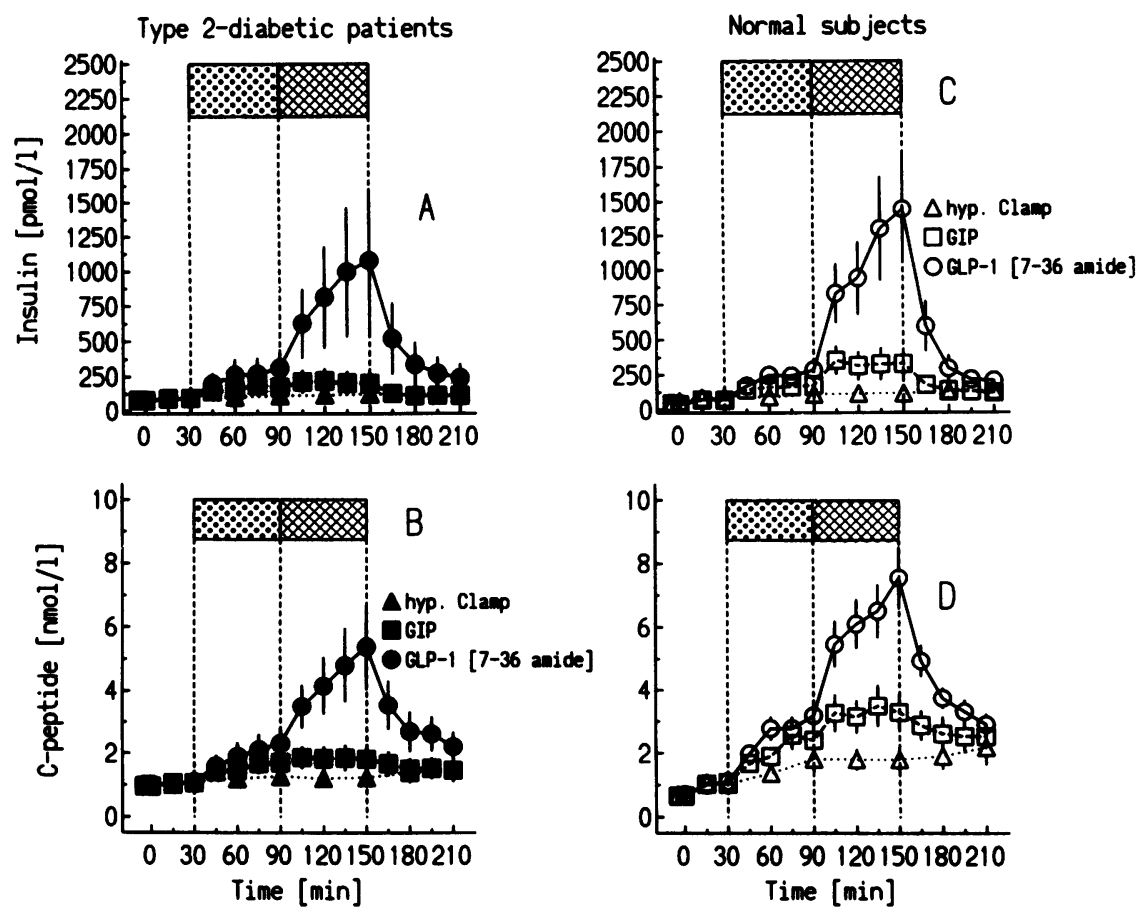

Figure 3. Immunoreactive insulin (upper panels) and C-peptide (lower panels) during hyperglycemic clamp experiments with and without the infusion of synthetic human GIP or GLP-1 [7-36 amide] in type-2 diabetic patients (left panels) and normal subjects (right panels). Mean \pm SEM. For statistical analysis, see Tab. II. The dotted lines separate periods of low $(x)$ and high $(\square)$ dose administration of GIP or GLP-1 [ 7-36 amide]. 
Table II. Insulinotropic Activity of Synthetic Human GIP and GLP-1 [7-36 Amide] during Hyperglycemic Clamp Experiments in Type-2 Diabetic Patients and Normal Subjects

\begin{tabular}{|c|c|c|c|c|}
\hline \multirow{2}{*}{$\begin{array}{c}\text { Parameter (unit) } \\
\text { Patient/subject group }\end{array}$} & \multicolumn{2}{|c|}{ GIP } & \multicolumn{2}{|c|}{ GLP-1 [7-36 amide] } \\
\hline & Low rate* & High rate ${ }^{\ddagger}$ & Low rate & High ratell \\
\hline \multicolumn{5}{|l|}{ Insulin (nmol liter ${ }^{-1}$ min) } \\
\hline Type-2 diabetic patients & $3.0 \pm 1.0$ & $7.7 \pm 3.2^{1}$ & $7.5 \pm 3.7$ & $38.2 \pm 18.0^{\prime}$ \\
\hline Normal subjects & $4.0 \pm 0.8$ & $18.0 \pm 6.8^{1}$ & $7.4 \pm 1.3$ & $51.4 \pm 14.7^{1}$ \\
\hline$P$ value & 0.14 & 0.047 & 0.085 & 0.145 \\
\hline \multicolumn{5}{|l|}{ C-peptide (nmol liter ${ }^{-1} \mathrm{~min}$ ) } \\
\hline Type- 2 diabetic patients & $16.0 \pm 3.0$ & $35.6 \pm 6.9^{1}$ & $39.4 \pm 9.7$ & $164.1 \pm 38.3^{1}$ \\
\hline Normal subjects & $36.6 \pm 6.9$ & $77.6 \pm 20.8^{1}$ & $59.1 \pm 21.1$ & $229.7 \pm 32.3^{\prime}$ \\
\hline$P$ value & 0.19 & 0.047 & 0.20 & 0.085 \\
\hline \multicolumn{5}{|l|}{ Glucose infusion $(m g / k g)$} \\
\hline Type-2 diabetic patients & $11.7 \pm 9.1$ & $27.1 \pm 10.3$ & $28.3 \pm 9.6$ & $140.9 \pm 19.98^{1}$ \\
\hline Normal subjects & $94.1 \pm 25.2$ & $270.6 \pm 46.9$ & $101.5 \pm 25.2$ & $426.7 \pm 53.0^{\prime}$ \\
\hline$P$ value & 0.009 & 0.0005 & 0.12 & 0.0005 \\
\hline
\end{tabular}

Activity is expressed as integrated incremental responses of insulin, C-peptide, and glucose infusion rates over the values measured in hyperglycemic clamp experiments without exogenous administration of insulinotropic hormones. Mean \pm SEM. Integrations were carried out over 60 min (the period of peptide hormone administration at a given infusion rate). ${ }^{*} 0.8 \mathrm{pmol} \mathrm{kg}^{-1} \mathrm{~min}^{-1} ;{ }^{\ddagger} 2.4 \mathrm{pmol} \mathrm{kg}^{-1} \mathrm{~min}^{-1} ;{ }^{8} 0.4 \mathrm{pmol} \mathrm{kg}^{-1}$ $\min ^{-1}$; $1.2 \mathrm{pmol} \mathrm{kg}^{-1} \mathrm{~min}^{-1}$; 'Significant difference (Wilcoxon-test; $P<0.05$ ) to the value observed with the lower dose of the same insulinotropic hormone.

tients (Fig. $4 A$ ). The low infusion rate of GLP-1 [ 7-36 amide] led to a $38.6 \%$ reduction in glucagon $(P=0.043)$, and the suppression reached $44.2 \%(P=0.046)$ at the high infusion rate.

\section{Discussion}

Among other defects in insulin secretion in type-2 diabetic patients, there is a reduced or absent incretin effect: insulin release is no longer stimulated more by oral as compared to "isoglycemic" intravenous glucose $(2,3,14)$. Due to the magnitude of the incretin effect (in normal subjects it contributes $\sim 25-60 \%$ to the insulin secretory response after and oral glu-
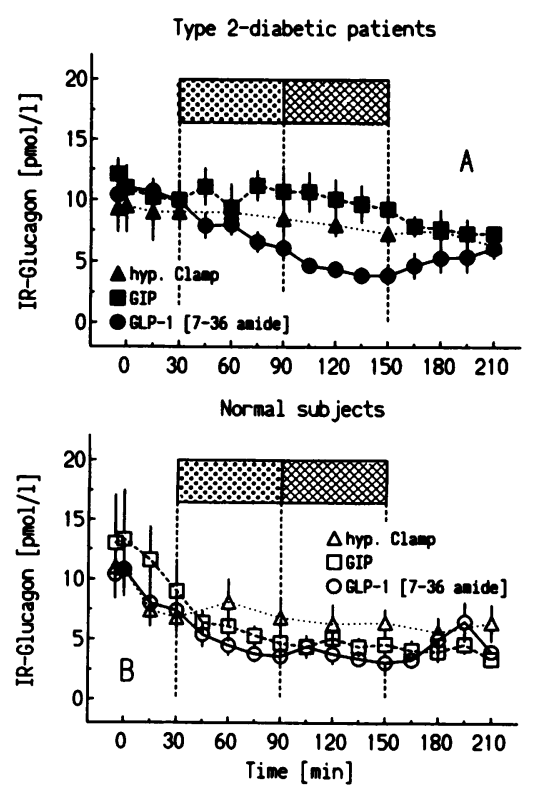

Figure 4. Pancreatic glucagon (antiserum 4305) during hyperglycemic clamp experiments with and without the infusion of synthetic human GIP or GLP-1 [7-36 amide] in type-2 diabetic patients (upper panel) and normal subjects (lower panel). Mean \pm SEM. The dotted lines separate periods of low (田) and high ( $\square$ ) dose administration of GIP or GLP-1 [7-36 amide]. For statistical analysis, see text. cose challenge, depending on the size of the glucose load; $2-4$, 32,33 ), its loss may partially be responsible for the diabetic glucose tolerance. Although the incretin effect has not been quantified in the current study, the characteristics of the type-2 diabetic patients were sufficiently similar to those studied previously (4) to assume a reduction in the overall incretin effect in them as well.

A reduced incretin effect can, in principle, be caused by impaired secretion of relevant incretin hormones or by B cell insensitivity towards their insulinotropic action. Assuming that GIP and GLP-1 [7-36 amide] are the incretin hormones that normally mediate the incretin effect $(6,10,11)$, previous studies do not support that they are released to a lesser extent in type- 2 diabetic patients. Only in some of them hyposecretion of GIP occurs (16). Therefore, the slightly reduced GIP response after oral glucose in the present study is compatible with the literature. GLP-1 [ 7-36 amide] responses in type-2 diabetic patients, in one study, were elevated in comparison to normal subjects (17). Using the same radioimmunoassay method, in the present study type-2 diabetic patients had lower incremental responses of immunoreactive GLP-1 than normal subjects (Fig. $1 E$ ). Therefore, the GLP-1 [7-36 amide] response to oral glucose seems to be as variable as is known in the case of GIP $(4,15,16)$.

Using natural or synthetic GIP of the porcine amino acid sequence, a reduced insulin secretory response has uniformly been described in type- 2 diabetic patients $(18,19)$. The present study confirms that also human GIP, at physiological or even pharmacological concentrations, does not stimulate insulin secretion in type-2 diabetic patients as it does in normal subjects (Fig. 3; Table II). In young volunteers, GIP appears to mediate a quantitatively major part of the incretin effect, because exogenous GIP in concentrations that approximately matched postprandial levels stimulated insulin secretion almost as good as did oral glucose $(6,11,34)$. Compared to our previous study 
(11), which was performed at the same time and using the same lot numbers of GIP, the insulin secretory response during GIP infusion appears to be smaller in the present group of older normal subjects. Although this has to be clarified by direct comparison, this observation is compatible with the hypothesis that the sensitivity of the B cell toward GIP is reduced with aging, as suggested by Elahi et al. $(35,36)$. Nevertheless, even if a reduced responsiveness to GIP is a typical phenomenon in normal subjects of the age group studied (Table I), the insulin secretory response to GIP infusion was further reduced in type2 diabetic patients.

Insulinotropic effects of GLP-1 [7-36 amide] in man have been reported in normal subjects $(10,11)$, and only recently data have been published in type- 2 diabetic patients using GLP-1 [7-37] (22), which in animal experiments is as insulinotropic as GLP-1 [7-36 amide] (37), the predominant secretory product of intestinal proglucagon processing (12). A comparison of effects in type- 2 diabetic patients and age- and weight-matched normal subjects under identical conditions has not been reported. The insulin secretory response after the administration of GLP-1 [ 7-36 amide] was surprisingly similar in normal subjects and type-2 diabetic patients (Fig. 3; Table II). The fact that the glucose infusion rate had to be increased during GLP-1 [7-36 amide] administration even in type-2 diabetic patients, is well compatible with the glucose-lowering effect observed with GLP-1 [7-37] (22). GLP-1 [7-36 amide] may, in addition, enhance insulin sensitivity to explain this effect (38). The difference in glucose infusion rates necessary to counteract the effects of similar immunoreactive insulin concentrations (Fig. 3; Table II) may be the consequence of a higher proportion of insulin immunoreactivity being proinsulin-like material in type-2 diabetic patients (39) and of their insulin resistance (40).

Judging from immunoreactive GIP responses after oral glucose and during low-dose intravenous infusion, (Figs. 1 and 2), GIP concentrations tended to be lower with exogenous administration. This may have compensated for the contribution of 8,000-D "GIP," which is not insulinotropic (41), but represents $\sim 30 \%$ of the GIP response to nutrients as measured with the antiserum used in the present study (42).

Owing to possible cross-reactions with GLP-1 [1-36 amide] or GLP-1 [1-37], which have a much lower insulinotropic activity compared to GLP-1 [7-36 amide] $(9,43,44)$, the overall response of GLP-1 immunoreactivity after glucose ingestion may overestimate the increment in "truncated," insulinotropic GLP-1 [ 7-36 amide], although the material administered intravenously was pure GLP-1 [7-36 amide]. The B cell secretory response observed in response to exogenous GLP-1 [7-36 amide], therefore, may lead to an overestimation of GLP-1 [7-36 amide] effects after the oral glucose challenge. Taking this and the additive interaction of GIP and GLP-1 [7-36 amide] (11) into account, the combined action of hyperglycemia, GIP, and GLP-1 [7-36 amide] very likely explains the amount of insulin secreted in response to oral glucose in normal subjects. In type-2 diabetic patients, GIP probably contributes little, and the increment in GLP-1 [7-36 amide] after oral glucose probably is not sufficient to maintain a normal incretin effect.

Glucagon secretion has been suppressed by GLP-1 [7-36 amide] in the isolated perfused pancreas (23-26) and a small effect has been noted, in the basal state, in healthy volunteers
$(10,27)$. The glucagon-lowering effect of GLP-1 [7-36 amide] was almost lost in the perfused pancreas of streptozotocin-diabetic rats (23). The present study, in contrast, demonstrates that GLP-1 [7-36 amide] is able to dose-dependently lower pancreatic glucagon in type- 2 diabetic patients (Fig. 4). The degree of suppression was similar to the one reached during hyperglycemia in normal subjects.

The present study, together with previously published data $(22,38)$, poses the question whether GLP-1 [7-36 amide] receptor agonists could be used pharmacologically to lower plasma glucose in type-2 diabetic patients. GIP is not suitable for this purpose, because its insulinotropic activity is almost lost in type-2 diabetic patients, even at supraphysiological concentrations (Figs. 2 and 3). GLP-1 [7-36 amide] may be a better candidate. In favor of this proposition are the well-preserved insulinotropic activity of GLP-1 [7-36 amide] (Fig. 3; Table II), its glucagon-lowering effect (Fig. 4), and possible inhibitory effects on gastric emptying rates $(27,38)$, which would lower the requirement for rapid insulin secretory responses as do other means of slowing nutrient absorption (45). Furthermore, GLP-1 [ 7-36 amide] does not considerably stimulate insulin secretion at basal plasma glucose concentrations $(10,11,37)$. This should limit the risk of hypoglycemia even at high, pharmacological concentrations of GLP-1 [ 7-36 amide].

In the present study only well-controlled type- 2 diabetic patients were studied. Further studies should clarify whether the preserved insulinotropic and glucagon-lowering activity of GLP-1 [7-36 amide] is also found in those type-2 diabetic patients, who need not only dietary restrictions but require additional therapy. Even if GLP-1 [ 7-36 amide] effects are limited to some type-2 diabetic patients, the close correlation of insulin secretory responses after glucagon injection and during GLP-1 [7-36 amide] administration suggests that these patients can be identified by their well-preserved C-peptide response after glucagon.

In conclusion, the reduced incretin effect in type- 2 diabetic patients is most likely explained by the reduced insulinotropic effectiveness of GIP. The plasma concentrations of true GLP-1 [7-36 amide] after oral glucose probably are not sufficient to maintain a normal incretin effect in type- 2 diabetic patients. However, the well-preserved insulinotropic effect, and the glucagon-lowering potency of GLP-1 [7-36 amide] in type-2 diabetic patients may be exploited to pharmacologically lower their plasma glucose concentrations.

\section{Acknowledgments}

The excellent technical assistance of Ms. S. Bierkamp, S. Ogilvie, A. Bernhard, W. Kopp, K. Illmer, and L. Mardrup is gratefully acknowledged.

This study was supported by the Deutsche Forschungsgemeinschaft, grant $\mathrm{Na} 203 / 2-1$.

\section{References}

1. Creutzfeldt, W. 1979. The incretin concept today. Diabetologia. 16:75-85.

2. Perley, M. J., and D. M. Kipnis. 1967. Plasma insulin responses to oral and intravenous glucose: studies in normal and diabetic subjects. J. Clin. Invest. 46:1954-1962.

3. Nauck, M. A., E. Homberger, E. G. Siegel, R. C. Allen, R. P. Eaton, R. Ebert, and W. Creutzfeldt. 1986. Incretin effect of increasing glucose loads in man calculated from venous insulin and C-peptide responses. J. Clin. Endocrinol. Metab. 63:492-498. 
4. Nauck, M., F. Stöckmann, R. Ebert, and W. Creutzfeldt. 1986. Reduced incretin effect in type 2 (non-insulin-dependent) diabetes. Diabetologia. 29:4652.

5. Dupré, J., S. A. Ross, D. Watson, and J. C. Brown. 1973. Stimulation of insulin secretion by gastric inhibitory polypeptide in man. J. Clin. Endocrinol. Metab. 37:826-828.

6. Nauck, M., W. Schmidt, R. Ebert, J. Strietzel, P. Cantor, G. Hoffmann, and W. Creutzfeldt. 1989. Insulinotropic properties of synthetic human gastric inhibitory polypeptide in man: interactions with glucose, phenylalanine, and cholecystokinin 8. J. Clin. Endocrinol. Metab. 69:654-662.

7. Buchan, A. M. J., J. M. Polak, C. Capella, E. Solcia, and A. G. E. Pearse. 1978. Electronimmunocytochemical evidence for the $\mathrm{K}$ cell localization of gastric inhibitory polypeptide (GIP) in man. Histochemistry. 56:37-44.

8. Holst, J. J., C. Ørskov, O. Vagn Nielsen, and T. Schwartz. 1987. Truncated glucagon-like peptide 1, an insulin-releasing hormone from the distal gut. FEBS (Fed. Eur. Biochem. Soc.) Lett. 211:169-174.

9. Mojsov, S., G. C. Weir, and J. F. Habener. 1987. Insulinotropin: glucagonlike peptide 1 (7-37) co-encoded in the glucagon gene is a potent stimulator of insulin release in the perfused rat pancreas. J. Clin. Invest. 79:616-619.

10. Kreymann, B., M. A. Ghatei, G. Williams, and S. R. Bloom. 1987. Glucagon-like peptide 1 7-36: a physiological incretin in man. Lancet. 2:1300-1304.

11. Nauck, M., E. Bartels, C. Ørskov, R. Ebert, and W. Creutzfeldt. 1991. Insulinotropic effects of a combination of human synthetic GIP and GLP-1 (7-36 amide) at physiological plasma glucose in man. Diabetologia. 34 (Suppl. 2):A14. (Abstr.)

12. Ørskov, C., M. Bersani, A. H. Johnsen, P. Horup, and J. J. Holst. 1989. Complete sequences of glucagon-like peptide- 1 from human and pig small intestine. J. Biol. Chem. 264:12826-12829.

13. Varndell, I. M., A. E. Bishop, K. L. Sikri, L. O. Uttenthal, S. R. Bloom, and J. M. Polak. 1985. Localization of glucagon-like peptide (GLP) immunoreactants in human gut and pancreas using light and electron microscopic immunocytochemistry. J. Histochem. Cytochem. 33:1080-1086

14. Tronier, B., A. Deigard, T. Andersen, and S. Madsbad. 1985. Absence of incretin effect in obese type 2 and diminished effect in lean type 2 and obese subjects. Diabetes Res. Clin. Pract. (Suppl. 1) S568. (Abstr.)

15. Krarup, T. 1988. Immunoreactive gastric inhibitory polypeptide. Endocr. Rev. 9:122-134.

16. Creutzfeldt, W. R. Ebert, M. Nauck, and F. Stöckmann. 1983. Disturbances of the entero-insular axis. Scand. J. Gastroenterol. Suppl. 83:111-119.

17. Orskov, C., J. Jeppesen, S. Madsbad, and J. J. Holst. 1991. Proglucagon products in plasma of noninsulin-dependent diabetics and nondiabetic controls in the fasting state and after oral glucose and intravenous arginine. J. Clin. Invest. 87:415-423.

18. Jones, I. R., D. R. Owens, A. J. Moody, S. D. Luzio, T. Morris, and T. M. Hayes. 1987. The effects of glucose-dependent insulinotropic peptide infused at physiological concentrations in normal subjects and type 2 (non-insulin-dependent) diabetic patients on glucose tolerance and B-cell secretion. Diabetologia. 30:707-712.

19. Krarup, T., N. Saurbrey, A. J. Moody, C. Kühl, and S. Madsbad. 1987. Effects of porcine gastric inhibitory polypeptide on beta-cell function in type and II diabetes mellitus. Metab. Clin. Exp. 36:677-682.

20. Jörnvall, H., M. Carlquist, S. Kwauk, S. C. Otte, C. H. S. McIntosh, J. C. Brown, and V. Mutt. 1981. Amino acid sequence and heterogeneity of gastric inhibitory polypeptide (GIP). FEBS (Fed. Eur. Biochem. Soc.) Lett. 123:205210 .

21. Moody, A. J., L. Thim, and I. Valverde, I. 1984. The isolation and sequencing of human gastric inhibitory polypeptide (GIP). FEBS (Fed. Eur. Biochem. Soc.) Lett. 172:142-148.

22. Nathan, D. M., E. Schreiber, H. Fogel, S. Mojsov, and J. F. Habener. 1992. Insulinotropic action of glucagon-like peptide-I-(7-37) in diabetic and nondiabetic subjects. Diabetes Care. 15:270-276.

23. Suzuki, S., K. Kawai, S. Ohashi, H. Mukai, Y. Murayama, and K. Yamashita. 1990. Reduced insulinotropic effects of glucagonlike peptide 1-(7-36)amide and gastric inhibitory polypeptide in isolated perfused diabetic rat pancreas. Diabetes. 39:1320-1325.
24. Ørskov, C., J. J. Holst, and O. V. Nielsen. 1988. Effect of glucagon-like peptide 1 (proglucagon (78-107) amide) on endocrine secretion from pig pancreas, antrum and nonantral stomach. Endocrinology. 123:2009-2013.

25. Komatsu, R., T. Matsuyama, M. Namba, N. Watanabe, H. Itoh, N. Kono, and S. Tarui. 1989. Glucagonostatic and insulinotropic action of glucagonlike peptide 1-(7-36)-amide. Diabetes. 38:902-905.

26. Kawai, K., S. Suzuki, S. Ohashi, H. Mukai, H. Ohmori, Y. Murayama, and K. Yamashita. 1989. Comparison of the effects of glucagon-like peptide-1(1-37) and (7-37) and glucagon on islet hormone release from the isolated perfused canine and rat pancreases. Endocrinology. 124:1768-1773.

27. Schjoldager, B., A. Wettergren, P. E. Mortensen, J. Myhre, C. Ørskov, J. Christiansen, and J. J. Holst. 1990. Truncated GLP-1 (proglucagon 78-107 amide): a possible incretin from the distal gut. Diabetologia. 33 (Suppl. 1):A99. (Abstr.)

28. DeFronzo, R. A., J. D. Tobin, and R. Andres. 1979. Glucose clamp technique: a method for quantifying insulin secretion and resistance. Am. J. Physiol. 237:E214-223.

29. Kuzio, M., J. R. Dryburgh, K. M. Malloy, and J. C. Brown. 1974. Radioimmunoassay for gastric inhibitory polypeptide. Gastroenterology 66:357-364.

30. Ørskov, C., and J. J. Holst. 1987. Radio-immunoassays for glucagon-like peptides 1 and 2 (GLP-1 and GLP-2). Scand. J. Clin. Lab. Invest. 47:165-174.

31. Holst, J. J. 1982. Evidence that peak II GLI or enteroglucagon is identical to the C-terminal sequence (residues 33-69) of glicentin. Biochem. J. 207:381388.

32. Tillil, H., E. T. Shapiro, A. Miller, T. Karrison, B. H. Frank, J. A. Galloway, A. H. Rubenstein, and K. S. Polonsky. 1988. Dose-dependent effects of ora and intravenous glucose on insulin secretion and clearance in normal humans. Am. J. Physiol. 254:E349-357.

33. Shuster, L. T., V. W. L. Go, R. Rizza, P. C. O'Brien, and F. J. Service. 1988. Incretin effect due to increased secretion and decreased clearance of insulin in normal subjects. Diabetes. 37:200-203.

34. Füessl, H. S., Y. Yiangou, M. A. Ghatei, F. D. Goebel, and S. R. Bloom. 1990. Effect of synthetic human glucose-dependent insulinotropic polypeptide (hGIP) on the release of insulin in man. Eur. J. Clin. Invest. 20:525-529.

35. Elahi, D., D. K. Andersen, D. C. Muller, J. D. Tobin, J. C. Brown, and R. Andres. 1984. The enteric enhancement of glucose-stimulated insulin release: the role of GIP in aging, obesity, and non-insulin-dependent diabetes mellitus. Diabetes. 33:950-957.

36. Elahi, D., G. S. Meneilly, M. McAloon-Dyke, A. Slater, G. Wong, K. L. Minaker, and D. K. Anderson. 1990. The insulinotropic action of GIP in humans: glucose and hormone dose-response in relation to aging. Digestion. 46 (Suppl. 1):28. (Abstr.)

37. Weir, G. C., S. Mojsov, G. K. Hendrick, and J. F. Habener. 1989. Glucagonlike peptide 1 (7-37) actions on endocrine pancreas. Diabetes. 38:338-342.

38. Gutniak, M., C. Ørskov, J. J. Holst, B. Ahren, and S. Efendic. 1992. Antidiabetogenic effect of glucagon-like peptide-1 (7-36) amide in normal subjects and patients with diabetes mellitus. N. Engl. J. Med. 326:1316-1322.

39. Deacon, C. F., S. Schleser-Mohr, M. Ballmann, B. Willms, J. M. Conlon, W. Creutzfeldt. 1988. Preferential release of proinsulin relative to insulin in noninsulin-dependent diabetes mellitus. Acta Endocrinol. 119:549-554.

40. DeFronzo, R. A. 1988. The triumvirate; $\beta$-cell, muscle, liver. A collusion responsible for NIDDM. Diabetes. 37:667-687.

41. Krarup, T., J. J. Holst, S. Knuhtsen, A. J. Moody, V. O. Nielsen. 1987 Effect of porcine $\mathbf{8 0 0 0}$ dalton immunoreactive gastric inhibitory polypeptide in the isolated perfused pig pancreas. Diabetes. 36 (Suppl. 1):7 A. (Abstr.)

42. Krarup, T., and J. J. Holst. 1984. The heterogeneity of gastric inhibitory polypeptide in porcine and human gastrointestinal mucosa evaluated with five different antisera. Regul. Pept. 9:35-46.

43. Schmidt, W. E., E. G. Siegel, and W. Creutzfeldt. 1985. Glucagon-like peptide-1 but not glucagon-like peptide-2 stimulates insulin release from isolated rat pancreatic islets. Diabetologia. 28:704-707.

44. Shima, K., M. Hirota, and C. Ohboshi. 1988. Effect of glucagon-like peptide-1 on insulin secretion. Regul. Pept. 22:245-252.

45. Creutzfeldt, W., and U. R. Fölsch. 1983. Delaying Absorption as a Therapeutic Principle in Metabolic Disease. Georg-Thieme-Verlag, Stuttgart. 